\title{
District Education Offices Empowerment as a Learning Organization: Indicators of Change Management
}

\author{
Nurul Sahadila Abd Rani', Mohd Izham Mohd Hamzah²*, Azlin Norhaini Mansor² \\ ${ }^{1}$ Faculty of Education, Universiti Kebangsaan Malaysia (UKM), Bangi, Malaysia \\ ${ }^{2}$ Centre of Education Leadership \& Policy, Faculty of Education, Universiti Kebangsaan Malaysia, Bangi, Malaysia \\ Email: *izham@ukm.edu.my
}

How to cite this paper: Rani, N. S. A., Hamzah, M. I. M., \& Mansor, A. N. (2019). District Education Offices Empowerment as a Learning Organization: Indicators of Change Management. Creative Education, 10, 2968-2983.

https://doi.org/10.4236/ce.2019.1012221

Received: October 21, 2019

Accepted: November 26, 2019

Published: November 29, 2019

Copyright $\odot 2019$ by author(s) and Scientific Research Publishing Inc. This work is licensed under the Creative Commons Attribution International License (CC BY 4.0).

http://creativecommons.org/licenses/by/4.0/

\begin{abstract}
The purpose of this study is to determine the level of change management indicators in the context of empowering the District Education Office (DEO) and to explore whether indicators of implementation of change management in the context of the process of empowering the DEOs. This study uses an explanatory sequential design approach. A total of 103 Head of District Education Officers (HDEO) from all over Malaysia were randomly selected as survey respondents and seven interview participants. Data were analyzed using SPSS software version 2.2. Meanwhile, qualitative research using semi-structured interviews involved seven people, five HDEO and two Program Managers. Informants were selected using objective sampling and snowball sampling. Data were analyzed using Nvivo 11 software to construct the themes studied. The findings show that the level of empowerment in the District Education Office as a whole is very high with a mean score of 4.70 . The theme findings for indicators of change management implementation in the context of empowering DEO include six key themes namely roles and responsibilities (Head of Education Officer, Program Manager, SIPartners+ and SISC+), performance dialog, provision management, Key Performance Indicators (KPIs), dashboards and Ratings DEO excellence. This study is important to District Education Officers, Deputy District Education Officers and all officials including SIPartners+ and SISC+ as indicators are preliminary interventions to detect any issues or issues that may arise during implementation of the change program. Therefore, through these change indicators can be a guide to ensure that changes are made in accordance with DTP's plans and goals.
\end{abstract}

\section{Keywords}

Empowerment, Change Management, Indicators of Change, District Education Office, Malaysia 


\section{Introduction}

The need for 21st century skills has led many world nations to rally in enhancing creativity and innovation skills, advanced technology and leadership skills. The District Transformation Programme (DTP) under the framework of the Malaysian Education Development Plan (PPPM) 2013-2025 aims to accelerate improvement in school performance through a systematic program led by the District Education Office (DEO). The implementation of the DTP over four years has successfully bridged the gap between Primary School Assessment (Ujian Penilaian Sekolah Rendah-UPSR) and Secondary School Certificate (Sijil Peperiksaan Malaysia-SPM) between urban and rural schools. In 2016 in the PPPM 2013-2025 Annual Report 2013-2025, the national achievement gap between urban and rural schools drastically expanded by $26.3 \%$ for UPSR 2016 compared to UPSR 2012 and the achievement gap between urban and rural schools at SPM level continued to decrease by $22.9 \%$ compared to 2012 (Ministry of Education Malaysia, 2017a). In addition, schools receive authority to plan and make decisions based on the instructions received from the Ministry (Mansor et al., 2016).

The management and governance to enhance the efficiency of the education system remains a key issue in the issue of efficiency in the provision of public services, which is still a function of functioning especially the functions of the Ministry of Education Malaysia (MoEM), State Education Department (SED) and DEO. It is visualized as hierarchical, highly centralized, and heavy at the top (sector, division) but small at the bottom (district, school), bureaucratic issues, as well as inefficient and ineffective management of resources and personnel, and the implementation of certain policies (Mohamed Yusoff et al., 2018). In fact, the DEO are still bound by central command. This has resulted in the DEO having limited authority in making decisions, drafting plans for school improvement and improving student performance in their respective districts.

In addition, there are a number of problems in personal management and administration such as hierarchical and centralized ministry structures that may result in inefficient, bureaucratic and ineffective delivery systems in human resource management. Additionally, there are issues in implementing changes in DEO such as teachers' attitudes in which teachers do not implement classroom assessments, learning and programming $(P d P c)$ modules provided by DEO, teachers are in a comfortable zone and do not cooperate with School Improvement Specialist Coach + (Hamzah \& Rani, 2018). According to Hanim \& Mansor (2018) research, major findings revealed that the teachers viewed some aspects of the policy has increased their workload and also a glaring gap between the implementation of the programme in the schools and the knowledge of the policy among teachers.

One way to monitor transformation programs is through the construction of change indicators. Without indicators, DEO is difficult to monitor for changes 
that occur and will cause issues if no indicator is used as a benchmark for DTP change. The need for change indicators especially in the implementation of DTP may be a direct indication or notification whether or not the guidelines are set by the MoEM. This is supported by Mainguet \& Baye (2006) who find it difficult to respond to the success of a policy or program implemented without establishing indicators of change. In addition, the failure of organizational members to understand the concept of learning organization has also led to a culture of positive change resulting from a lack of exposure to the importance of learning organizations in DEO (Maidin, 2012). Finding research from Alias \& Mansor (2018) also show the lowest mean score for knowledge is to design effective staff development programs whereas for skills is to establish cooperation among subordinates.

\section{Indicators of Change Management at the District Education Office}

Implementation of the District Transformation Program (DTP) in the DEO requires change guidance in order for the change to be achieved. An indicator can then serve as a guide for measuring the course of change programs implemented. Indicators are also a guide to the achievement of a project whether it is in line with its goals and objectives or not (Lennie et al., 2011).

The Logic Model by Kellogg $(1998,2004)$ is the most basic description of a programmatic working process that consists of planning work (input/source, activity, output) and desired outcome (output, outcome, impact). The purpose of the Logic Model is to visualize the changes that are made through the work done with the desired results (Kellogg, 2004). Furthermore, in order to look at the process of empowerment of the DEO and what changes are occurring, the components of the District Transformation Program based on the Regional Transformation Program Handbook 3.0 (Ministry of Education Malaysia, 2017b) are also the basis of this study.

There are two main components to DTP: support and accountability. As for the support component, it involves two key things: empowering local leadership and providing support to the schools most in need. The component enables local leadership to focus on the role of the District Education Office in its role of increasing support for the school through School Improvement Partner+ (SIPartners+) for the support of principals, teachers and School Improvement Specialist Coach $+($ SISC +$)$ to guide teachers.

In addition, the components of accountability are made up of two aspects, namely the first to restrict access, quality and equity, and the second is the discipline of monitoring, problem solving and taking action. The DEO Performance Dashboard and the DEO Excellence Rating will be used for accessibility, quality and equity components while focusing on focused intervention actions to achieve the Key Performance Indicator (KPI). The Performance Dialogue is used for the disciplines of monitoring, problem solving and action-taking. Therefore, the researcher will use the following components of activities and outcomes as follows: 


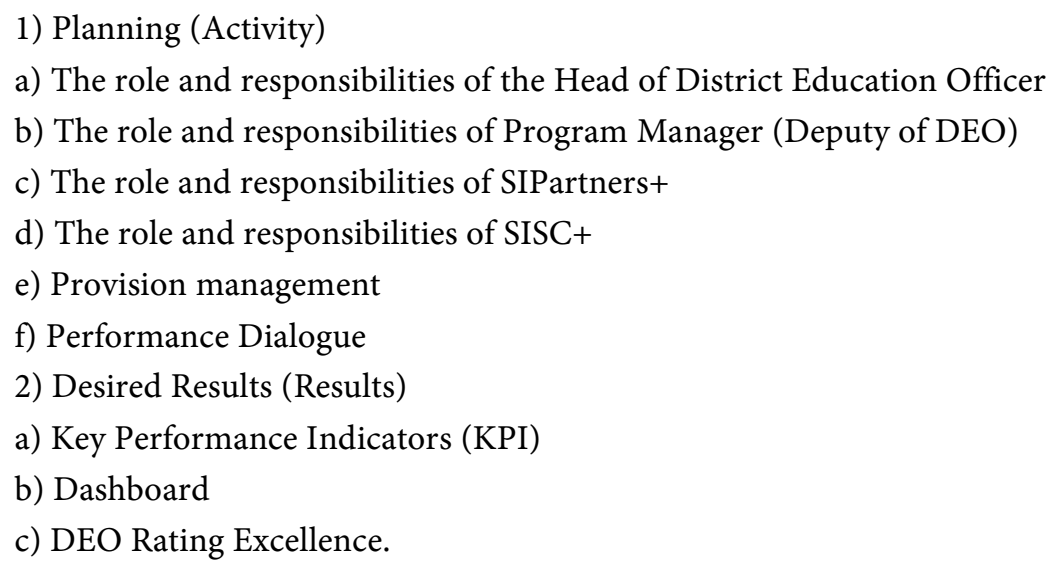

\section{Research Questions}

This study will answer two research questions: 1) What are the level of indicators of change management in the context of empowering the District Education Office? and 2) What is the implementation of change indicators in the context of the empowerment of the District Education Office in Malaysia?

\section{Methodology}

This study uses an explanatory sequential design approach with quantitative approach as the main method followed by qualitative method. Group sampling techniques and strata random sampling were used to determine the respondents of the study. A total of 103 Head of District Education Officers (HDEO) from 142 District Education Offices (DEO) throughout Malaysia from the five zones, North Zone, South Zone, Central Zone, East Zone and East Malaysia zone were randomly selected as survey respondents. In addition, the survey questionnaire was adapted in part from Laschinger's (2012) Conditions of Work Effectiveness Questionnaire (CWEQ I \& II), The Learning Organization Questionnaire for Schools by Park (2006), District 3.0 Transformation Program (DTP) book.

Researchers have appointed three panelists as consultants to evaluate the validity of the questionnaire. Overall, based on the panel's views on the questionnaire instrument, they agreed and accepted all the constructions with minimal modifications. In addition, a pilot study was conducted involving $30 \mathrm{HDEO}$ with a total Cronbach Alpha value of 0.792 which is acceptable and in good agreement with Creswell (2012) and Pallant (2005). Data were analyzed using SPSS software version 2.2.

For the qualitative one, using the semi-structured interview method. Informants were selected using objective sampling and snowball sampling. The officers involved were seven comprising five District Education Officers and two Program Managers representing four zones namely the North Zone, South Zone, East Zone and Central Zone. Researchers use Nvivo 11 software to manage transcribed data. In order to determine the reliability of the data, the researchers have obtained a coefficient of agreement. The themes and sub-themes of this 
study have been acknowledged by several experts in providing Cohen Kappa approval. This study used three experts who evaluated the suitability of the data (with their consent) provided with the definition of the construct used. The obtained Cohen Kappa value is 0.822 which is considered to be very strong based on Landis \& Koch (1977) in Idris (2013).

\section{Finding and Discussion}

The first objective is to determine the level of change management indicators in the context of empowering the District Education Office. The overall results for the level of change management indicators are as shown in Table 1.

Table 1 shows the level of change management indicators in the context of empowering the District Education Office as a whole with a high score of 4.67. For the job planning component (activity) the highest mean $(\min =4.68, \mathrm{SP}=$ 0.33 ) was followed by the desired outcome component (outcome) (mean $=4.60$, SP 0.42). This indicates that change management indicators have been implemented well in the District Education Office. Overall, the findings show that the six indicators of change management for planning (activity) components are at a very high level. This shows that the indicators for the activity components are well implemented to enable the high performance component indicators to be high.

Furthermore, the second objective was developed to explore the informants' broad views on whether indicators of change in the context of empowering the District Education Office (DEO) through the District Transformation Program (DTP).

A total of five District Education Offices including two State Education Departments were involved in this study to represent the four selected zones, namely North Zone, South Zone, East Zone and Central Zone. Seven (7) officers were involved, consisting of five District Education Officers and two Program Managers (Table 2).

The results of the study found that the themes for indicators of change management implementation in the context of empowering DEO include six key themes namely roles and responsibilities in DTP, performance dialog, provision management, Key Performance Indicators (KPIs), dashboards and DEO Excellence Rating as shown in Figure 1.

\subsection{The Role and Responsibilities}

The first theme is the roles and responsibilities of four themes namely the Head of Education Officer (HDEO), Deputy District Education Officer (Program Manager), SIPartners+ and SISC+.

The roles and responsibilities of the HDEO are divided into more specific sub-categories such as 1) chairing the Performance Dialogue, 2), providing school leadership development programs 3), working with external parties and 4) Instructional guidance. The HDEO is responsible for chairing a performance dialogue with the Principal and the Headmaster to find out the issues and 
Table 1. Mean score, standard deviation and interpretation of change management indicators.

\begin{tabular}{lccc}
\hline \multicolumn{1}{c}{ Variable } & Mean & SD & Interpretation \\
\hline \multicolumn{1}{c}{ Planning (Activity) } & & & \\
\hline $\begin{array}{l}\text { The role and responsibilities of the Head of District } \\
\text { Education Officer } \\
\text { The role and responsibilities of Program Manager } \\
\text { (Deputy of DEO) }\end{array}$ & 4.67 & 0.32 & Very high \\
The role and responsibilities of SIPartners+ & 4.66 & 0.39 & Very high \\
The role and responsibilities of SISC+ & 4.68 & 0.39 & Very high \\
$\begin{array}{l}\text { Provision Management } \\
\text { Performance Dialogue }\end{array}$ & 4.72 & 0.38 & Very high \\
Total Planning (Activity) & 4.69 & 0.41 & Very high \\
& 4.71 & 0.40 & Very high \\
\hline Kesired Results (Results) & 4.68 & 0.33 & Very high \\
Dashboard & & & \\
DEO Rating Excellence & 4.58 & 0.46 & Very high \\
Total Desired Result (Result) & 4.58 & 0.45 & Very high \\
Total Change Management Indicators & 4.67 & 0.47 & Very high \\
\hline
\end{tabular}

Table 2. The informant for the semi-structured interviews.

\begin{tabular}{cccc}
\hline Informant & Position & Service Period & State \\
\hline HDEO1 & Head of District Education Officer & Less than one year & Selangor \\
HDEO2 & Head of District Education Officer & 2 years & Melaka \\
HDEO3 & Head of District Education Officer & 5 years & Johor \\
PM4 & Program Manager & More than 11 years & Putrajaya \\
HDEO5 & Head of District Education Officer & 2 years & Perak \\
PM6 & Program Manager & 3 years & Kedah \\
HDEO7 & Head of District Education Officer & 2 years & Kelantan \\
\hline
\end{tabular}

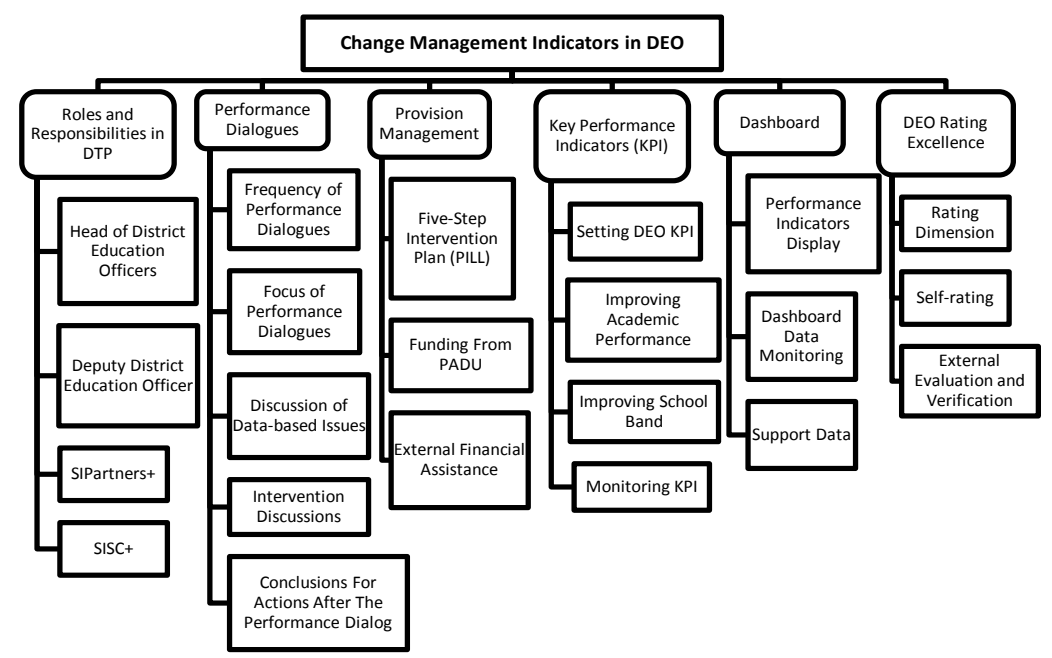

Figure 1. The themes for indicators of change management implementation in DEO.

problems at school and the best interventions to address them. The role and responsibilities of District Education Officers are to chair the Performance dialog, based on excerpts such as: 
"This performance dialogue is my personal responsibility because it is my duty to handle the performance dialogue where we (HDEO) ourselves have to take on a great responsibility and we cannot afford to lose it to others." (HDEO7).

The HDEO as leader in the DEO has the responsibility of chairing a performance dialogue with the Principal and the Headmaster to discuss issues that occur in schools where this task cannot be delegated to other officers unless taken by the Deputy DEO or delayed to a new date. In addition, the HDEO is also responsible for providing development programs for school leaders such as Principals and Teachers as well as senior leaders. HDEO empowers Principals and middle leaders through their meetings as well as special programs such as senior assistant leader training courses held at least twice a year. According to the District Transformation Program Management Handbook 3 (2017b), the allocation of tasks and responsibilities by the percentage of time spent on school leadership and administrative, academic and co-academic tasks is $15 \%$.

Further, the study also found that the HDEO also cooperated with external parties in implementing changes in the DEO. This is in line with a statement from the HDEO5 District Office stating that:

"We have a collaboration with the public welfare department, with the Police and some of the other agencies we call, with the Religious Council and we explain and we have a list of the names of school children who cannot be completed." (HDEO5).

Collaboration should be undertaken to build relationships with outside parties to enable intervention programs such as school dropout issues where there is cooperation with the Police to conduct raids in areas identified as student centers. According to the District Transformation Program Management Handbook 3 (2017b), the HDEO also has a 35\% duty and responsibility to support planning or programs, implementing district-level programs or activities as well as engagement with stakeholders and state administration.

In addition, HDEO's role and responsibilities are also to provide support to the school through four-part instructional guidance, focusing on aspects of school achievement, helping schools identify data-based strategic issues, guiding school leaders in day-to-day management and monitoring implementation or action. At the school level. This finding is in line with the findings of Azeez et al, (2015) which show that the role of instructional leadership is to oversee supervision and focus on the curriculum in an effort to improve school performance as a whole. According to Veelen et al. (2017) school leaders are highly autonomous and, thus, expected to be capable of developing their own system of quality assurance through reliable and valid self-evaluation, and to provide information on performance indicators, such as student achievement, parent satisfaction, and teacher professionalization

Next, for the Deputy Head of District Education Officer role and responsibilities are as Program Managers consisting of five roles such as 1) monitoring school performance, 2) implementing follow-up, 3) planning intervention programs, 4) implementing data-based intervention programs and 5) attend role 
briefings. The program manager plays a role in monitoring the performance of the school through performance dialogues or through data and reports obtained. The PM4 Program Manager conducts the monitoring during the performance dialogue sessions as well as through regularly received reports such as statements.

"As we recently did (performance dialogue), it was elementary school morning and at 11 o'clock we called high school. So, what you want to achieve in general, middle and low is heard. So, that's how we monitor our school performance and we focus" (PM4).

In addition, the DEO 6 Program Manager also implemented follow-up reports requested by the school to ensure that the school implemented the intervention program as directed. According to the District Transformation Program Management Handbook 3 (2017b), the Program Manager is responsible for monitoring, measuring and reporting school performance to DEO as well as managing follow-up and continuous improvement of DTP implementation. In addition, in carrying out the role of program manager, access to information is important in planning tasks; either to monitor, guide or take action to ensure that the intervention taken will give a positive impact on the schools' achievement. This is also in line with Thuss et al. (2016)'s study where information is important in the process of empowering the learning environment in health care practices.

The qualitative analysis also found that School Improvement Partners (SIPartners+) had the roles and responsibilities of three key roles, namely 1) mentoring to Principal and Headmaster $(P G B)$ through coaching and mentoring, 2) training aspects and 3) weekly reporting. The interview found that SIPartners+ provided guidance to principals and principals through coaching and mentoring based on three aspects such as school achievement, guidance for data-based school improvement and school administrator leadership. SIPartners+ in DEO5 applies guidance to schools that are in the lowest band in the region as follows:

"So this year 2018 we are still referring to schools that are focused on schools even though there are no bands but the data we are still using, 2015 data is band-based, as it relates to the District Transformation Program handbook. So by 2018 we are referring to the lower band schools in our area." (SIP+ DEO5).

In addition, SIPartners+ in DEO6 also implemented guidance for school improvement based on the needs and data obtained from the DEO Profile. Subsequently, SIPartners+ also conducted guidance to Novis $P G B$ where SIPartners+ DEO2 applied to schools with newly appointed Principals and held the IAB Residency and Immersion Program (PRIme). SIPartners+ DEO6 also stated that more than 50\% of new Principal and Headmaster were appointed and that they needed guidance from SIPartners+ especially in terms of school management. SIPartners+ DEO6 also provides guidance on aspects of school administration leadership, management, leadership and senior leadership.

In addition, SIPartners+ is also responsible for providing training and training 
where DEO6 Program Managers stated that SIPartners+ received courses from Institut Aminnudin Baki (IAB) to obtain information such as DTP and Principal leadership, Headmaster at school. While SIPartners+ DEO6 conducts training on $P G B$ such as implementing strategic planning to help $P G B$ understand dashboard data and how to take further action. This finding is in line with the findings of a study by Rani et al. (2018) who found that training and development can positively influence employees. In addition, based on the findings of the interviews, SIPartners+ is responsible for executing weekly reports to the HDEO. SIPartners+ DEO6 conducts weekly reporting online within Google Drive to facilitate HDEO to make DTP reports and bring them to meetings to discuss issues and interventions that need to be taken.

Finally, there are also the roles and responsibilities of School Improvement Specialist Coaches (SISC+) which comprise three main roles, namely 1) mentoring of teachers in learning and programming $\left(P d P_{c}\right)$ Coaching \& Mentoring, 2 ) training aspects, and 3) weekly reporting. The qualitative analysis showed that SISC+ applied guidance to the teacher-led $(G D B)$ through three mentoring processes, namely pre-guidance involving five aspects of school achievement, mentoring needs, rapport building and mentoring with teachers, principal and principal discussions, and request from HDEO or Principal Headmaster; second during the five-point guidance, expert on pedagogy, focus on $P d P c 21^{\text {st }}$ century learning $(P A K 21)$, across subjects, based on the matrix of Teacher Guidance (TCT) \& Teacher Development Plan, and frequency of guidance; and the third post-guidance.

For pre-guidance, SISC+ DEO2 focuses on schools that are in the lowest band to guide teachers and PM4 Program Managers find that SISC+ also guides according to the needs of teachers who need guidance in a school. Said et al. (2016) also stated that the focus of the SISC+ mentoring and mentoring program is subject to the Standard Operating Procedures (SOPs) set by the MoEM, which is a priority for low performing schools (Band 4, 5, 6, and 7). Prior guidance is essential to build rapport with GDB to determine what weaknesses need to be addressed. SISC+ DEO2 was found to build rapport before implementing the GROW (Goal, Reality, Obstacle/Options, Way forward) concept to ensure that friendly relationships were built so that GDB would feel comfortable sharing problems while teaching. This finding is in line with the findings of Huong \& Abdullah's (2018) study that GDB concedes that SISC+ is a good mentor and can build good relationships with mentors.

In addition, SISC+ DEO2 also held discussions with the Principal and the Headmaster to determine which teachers should be guided based on the data obtained. Further, the findings also indicate that SISC+ DEO5 applied to the $G D B$ based on recommendations and requests from the HDEO or the Principals to provide guidance to schools and teachers in need of guidance. Furthermore, during the guidance, the HDEO2 found that SISC+ is a pedagogical consultant and SISC+ guides the $G D B$, so that $G D B$ can use pedagogical methods that are appropriate to the student's ability level. It's like the statement: 
"So we coach the teachers, we guide the teachers so that we can expose the teachers in a pedagogical way that suits the student's ability level. We're coach, coaching doesn't have to be in the classroom. If we see that the teacher cannot control the class, then we go to pair teaching..." (HDEO2).

According to the District Transformation Program Management Handbook 3 (2017b) it states that SISC+ is an expert in pedagogy and curriculum (learning). Subsequently, SISC DEO2 also implemented guidance by focusing on $P d P c$ $P A K 21$, making the teaching and facilitating $(P d P c)$ of the teacher more interesting, effective, creative and innovative as the current developments (Huong \& Abdullah, 2018).

SISC+ also conducts cross-disciplinary guidance where DTP 3.0 is no longer confined to three subjects. SISC+DEO2 and the DEO6 Program Manager found that SISC+ implemented cross-curricular guidance based on the DTP 3.0 handbook, which is no longer focused on the Bahasa Malaysia, English and Math subjects as SISC+ is a pedagogical guide. Furthermore, based on the District Transformation Program Management Handbook 3.0 (2017b), during the guidance, SISC+ held discussions based on the Teacher Coaching Tools (TCT). The findings indicate that $\mathrm{SISC}+\mathrm{DEO} 2, \mathrm{DEO} 5$ and $\mathrm{DEO} 6$ implement $G D B$ guidance based on TCT and Teacher Development Plan in case of serious issues that need attention.

In addition, SISC+ DEO2 implemented three-round guidance to schools, but SISC+ DEO6 stated that the guidance taken was only involved in the second round because $G D B$ had successfully implemented pedagogy. This finding is in line with the findings of Said et al. (2016) who found that only two of the 22 monitored teachers reached the level and did not need to be repeated as they had achieved level three in any of the three elements recorded in the matrix form TCT. Finally, in the mentorship process conducted by SISC+ DEO6 is the post-guidance to see the level of achievement of $G B D$ guidance after being given a coaching session. In addition, SISC+ also conducts training and receives training. SISC+ DEO6 provides training to the $G D B$ in the event of a need to disclose examples of "differentiated learning". This is based on statements such as:

"...if I come across an issue, I want all teachers $(G D B)$ to know about differentiated learning, so when I go see 25 people who do not master differentiated learning. So I set one day to talk academically, so this is what we need to do, we plan together we do differentiated learning, so we focus." (SISC+ DEO6).

While SISC+ DEO5 receives coaching related training at IAB such as "design thinking" or pedagogical methods provided by IAB lecturers. Based on the findings of Huong \& Abdullah (2018) study, a group of interim teachers placed in schools had no teaching experience or were never exposed to pedagogical courses. Therefore, SISC+ needs to provide training and courses to $G D B$ on pedagogy so that teachers can plan their lessons well. Subsequently, SISC+ also served as the weekly reporting unit where $\mathrm{HDEO} 7$ found that SISC+ made weekly reports to HDEO for their guidance to schools or to discuss important issues and interventions that could be made to $G D B$. 


\subsection{Performance Dialogue}

Collectively, the feedback obtained from the Informant interview provided a variety of views on the implementation of the Performance Dialogue conducted at the DEO. More specifically, the implementation of the Performance Dialogue can be detailed in aspects such as 1) frequency of performance dialogues, 2) focus of performance dialogues, 3) discussion of data-based issues, 4) intervention discussions and 5) conclusions for actions after the performance dialog. Based on the findings of the study, $\mathrm{HDEO} 3$ frequency of performance dialogues is in accordance with the needs of the districts. Subsequently, the implementation of performance dialogues focused on issues and issues at school such as student discipline, attendance and dropout, subject and school performance issues. The PM4 Program Manager found that the implementation of performance dialogues was more focused as DEO would only engage with the schools involved and focus on one issue to discuss. This allows for important issues and problems to be resolved immediately. It's like the statement:

"...Identify in the area there are five schools with similar problems, say the school had many students late, so we will only call these five schools for a dialogue session and we will focus on school discipline issues because if we take on a lot of issues later in the discussion." (PM4).

In addition, PM4 Program Manager stated that in the performance dialog will discuss issues based on the latest data obtained from dashboard data or DEO Profile data and discuss the best interventions that can be implemented. Finally, there is a formulation for action after the performance dialog by looking at two aspects: proposals and actions where there are suggestions from the DEO or SED itself or suggestions from the Principal and Headmaster. The DEO 6 Program Manager found that at the end of the Discussion Dialogue, there were suggestions given by the DEO or the school itself and after the joint discussion, the best course of action was to be taken by the parties involved.

\subsection{Provision Management}

The qualitative feedback obtained reflects a broad range of views of Informants' research on the management of provisions in implementing DTP. In particular, the various perspectives include aspects such as 1) Five-Step Intervention Plan $(P I L L), 2)$ funding from PADU and 3) external financial assistance. The qualitative findings also indicate that the PILL aspects include application of budget, program implementation and expenditure as well as spending controls. The Program Manager found that for the grant application, the DEO had to create a PILL to implement the intervention programs and had to present it to PADU and Bahagian Pengurusan Sekolah Harian (BPSH). This is as stated by PM4:

“...We will ask (via PILL) first then we will have a pitching session. Pitching means we are fighting with PADU and BPSH. They will see whether or not what we want to do..." (PM4).

During the implementation of the PILL, the HDEO will discuss with the rele- 
vant officers to identify the best issues and interventions that can be implemented. This finding is in line with the findings of Aru et al. (2018) which showed that the Headmaster gave his subordinates the opportunity to give their views and ideas on the distribution of grant per capita subjects in the meeting and then to make a decision together. The allocation of funds also involves financial assistance from external parties. The HDEO2 found that there was help from parties such as provided assistance mainly for the achievement of $21^{\text {st }}$ Century Education such as LCD donations and projectors. This finding is supported by the findings of Radzi et al. (2018) which show that schools are welcoming financial support from stakeholders and parents such as donations or donations for school improvement. Financial assistance from external parties greatly helps the DEO to make good changes.

\subsection{Key Performance Indicators (KPI)}

Data from in-depth interview sessions show that Key Performance Indicators (KPI) can be divided into aspects such as 1) setting DEO KPI, 2) improving academic performance, 3) improving School Band and 4) monitoring KPI. For the setting of DEO KPI, there have been significant changes starting in 2018 where KPI will be set from below, namely, schools and KPI of schools in the district to average KPI DEO, SED and then Ministry KPI. The Pm4 found that the DEO KPI is no longer set by the Ministry, but the school will determine how many KPI can be achieved in this way, the school will be more prepared to ensure the KPI is achieved. It's like the statement:

"...So all the schools will send us a check, and then we will have the district KPI bring to the Department and the Department to the Ministry. So in that sense, schools will be more prepared by ensuring that KPIs are achieved. (PM6).

As for setting up DEO KPI, PM4 explained that setting KPI requires consultation with the school and this requires communication and knowledge to ensure DEO KPI are relevant and achievable. The findings are in line with a study by Bala \& Koxhaj (2017) which states that leaders of an organization need to focus on communication and understanding aspects to ensure that organizations understand the relevant KPIs and when monitoring the KPI. Furthermore, KPI in DEO also include academic performance improvement KPI where HDEO3 explained that KPI in terms of student achievement dominate and improve public examinations, UPSR examinations as well as $S P M$. In addition, there is also monitoring of KPIs as stated by the PM6. Establishing KPI should be implemented to ensure that schools set KPI better than ever and to ensure that schools achieve their KPI. The HDEO1 also stated that monitoring of KPI is done at weekly, monthly and annual meetings to get feedback on the KPI's achievements.

\subsection{Dashboard}

Data from in-depth interview sessions show that dashboards can be divided into aspects such as 1) performance indicators display, 2) dashboard data monitoring 
and 3) support data. In the performance indicators view, there are eight displays that include data such as student attendance data, student drop-out data, UPSR assessment data, critical subject data, School Average (GPS) data, student discipline data, guidance visitation data, and teacher attendance data. Based on this data DEO can analyze performance, implement intervention plans to address school issues and monitoring school data. In addition, the PM4 found that the dashboard was also used to monitor school performance, such as the statement:

"The purpose of the dashboard is to monitor the performance of the school. So the school will be alert, very good to monitor the performance of the school, so good that it cannot manipulate data..." (PM4).

The data in the dashboard is important to ensure that existing problems are resolved and to improve the effectiveness of the work performed for schools under their respective. This is in line with Kanter's (1993) view that information refers to permission to use data to improve work efficiency. In addition, the dashboard is open with supporting data due to problems with the Dashboard's current data usage. PM4 uses supporting data such as Student Database Application $(A P D M)$ to find out student attendance data. There are a number of HDEO who say the dashboard is still undergoing improvements that may be due to system problems or poor accessibility. This finding is in line with the findings of Phang et al. (2014) and Singh et al. (2017), a factor that prevents teachers from using the Geographic Information System (GIS) in their teaching that schools do not have GIS software and infrastructure equipment requirements for the implementation of $P d P c$ is aided by ICT in the teaching of Science.

\subsection{DEO Rating Excellence}

For excellence rating the District Education Office can be divided into several aspects such as 1) rating dimension, 2) self-rating and 3) external evaluation and verification. PM4 explained that the dimensions of success include assessments such as parent and community involvement, school success and national achievement. It's like the statement:

"The third dimension is the success of the DEO itself such as the District Average Grade, there is parental involvement, there is national achievement, there is achievement, it is the success of the school. Three dimensions to success, meaning school success..." (PM4).

Furthermore, for the leadership dimension, the PM4 found that the leadership dimension involved the assessment of District Education Officers and Deputy District Education Officers while the organizational dimension involved all organizational members. This finding is in line with the Regional Transformation Program Handbook 3.0 (2017) where the HDEO dimension contains leadership dimensions (30\%), organizational dimensions (50\%) and success dimensions (20\%). In addition, the DEO also includes self-ratings such as statements by PM4, HDEO3 and HDEO1 that DEO will make self-assessments in consultation with units such as service units, financial units and academic units to score based on the evidence and data that support that score. Next, there is an external 
review and verification of the rating made by the DEO. This finding also supports the statement in the District Transformation Program Management Handbook 3.0 (2017) that there is a collection of rating and verification data by the SED and the Ministry for DEOs that exceed the standards.

So, overall, the indicators such as the indicators developed in this study can provide complete information on any changes that are being made. This finding supports the statement by the OECD (2015) which states that indicators can provide information on human and financial resources invested in education, how education and learning systems operate and grow and return on investment in education.

\section{Implication}

Based on the findings, this study supports and strengthens both the components of the activity and the outcome components in Kellogg's (1998, 2004) Logic Model. The findings show that implementation activities of change management indicators in the context of DTP include roles and responsibilities in DTP, performance dialog and provision management, while the results are Key Performance Indicators (KPI), dashboards and District Office Excellence Rating. The findings of this study are useful in explaining and analyzing the activities and outcomes of implementing changes through DTP. The findings of this study support the activities section and the results of this model which list in detail the roles and responsibilities including the activities performed. In summary, this Logic Model can be used as a guide to changes in the success of the District Transformation Program (DTP) achieved and to help HDEO monitor the change program in accordance with the guidelines. In the event of a problem, the indicator can detect the problem early enough to allow the intervention to take place without waiting for the program to complete.

\section{Conclusion}

Empowering DEO through indicators such as the role and responsibilities of the District Education Officer, the role and responsibilities of the Program Manager, the roles and responsibilities of SIPartners+, the roles and responsibilities of the SISC+, the Performance and Provision Management Dialogue, Key Performance Indicators (KPI), the Dashboard and the Office of District Education Excellence Rating can be used as an indicator to measure the success of changes that have been achieved, especially in the context of DTP in DEO. Therefore, the findings of this study can provide added value and positive implications for the implementation of the empowerment process and indicators can serve as a guide to ensure that changes are made in accordance with DTP planning and goals.

\section{Acknowledgements}

The researchers would like to acknowledge the Ministry of Higher Education (MOHE) for the financial funding of this research through Fundamental Re- 
search Grant Scheme (FRGS) [Code: FRGS/1/2016/SSI09/UKM/02/9], Research Grant FPEND 1 (GG-2019-031) and PP-FPEND-2019.

\section{Conflicts of Interest}

The authors declare no conflicts of interest regarding the publication of this paper.

\section{References}

Alias, B., \& Mansor, A. N. (2018). School Human Resource Management in Malaysia. Journal of Advanced Research in Dynamical and Control Systems, 10, 1361-1365.

Aru, I. K. M, Samsuddin, S., Zawawi, N. H., \& Ab Ghani, M. F. (2018). Kepimpinan Guru Besar dan keberkesanan pengurusan kewangan peruntukan geran perkapita sekolah rendah zon Bangsar. Jurnal Kepimpinan Pendidikan, 5, 26-44. (In Malay) https://jupidi.um.edu.my/article/view/11344

Azeez, K. I., Ibrahim, M. S., \& Mustapa, R. (2015). Kompetensi kepimpinan Instruksional di kalangan Pengetua sekolah: Satu kajian empirikal di negeri Selangor. Jurnal Kepimpinan Pendidikan, 1, 1-14. (In Malay)

Bala, A., \& Koxhaj, A. (2017). Key Performance Indicators (KPIs) in the Change Management of Public Administration. European Scientific Journal, 13, 278-283. https://doi.org/10.19044/esj.2017.v13n4p278

Creswell, J. (2012). Educational Research: Planning, Conducting and Evaluating Quantitative and Qualitative Research (4th ed.). Boston, MA: Pearson.

Hamid, A., \& Mansor, A. N. (2018). Teacher Perceptions of the Local Implementation of the District Transformation Programme in Malaysia. Advanced Science Letters, 24, 475-478. https://doi.org/10.1166/asl.2018.12043

Hamzah, M. I. M., \& Rani, N. S. A. (2018). Issues and Problems in Strengthening District Education Offices in Malaysia as a Learning Organization. Journal of Advanced Research in Dynamical and Control Systems, 10, 1795-1803.

Huong, W. S., \& Abdullah, N. A. E. (2018). Bimbingan dan pementoran pakar peningkatan sekolah (SISC+) menurut perspektif guru dibimbing (GDB). International Journal of Education, Psychology and Counseling, 3, 57-72. (In Malay)

Idris, N. (2013). Penyelidikan Dalam Pendidikan Edisi Kedua. Selangor: McGraw-Hill Education. (In Malay)

Kanter, R. M. (1993). Men and Women of the Corporation (2nd ed.). New York: Basic Books.

Kellogg, W. K. (1998). Foundation Evaluation Handbook. Enero.

Kellogg, W. K. (2004). WK Kellogg Foundation Logic Model Development Guide. Battle Creek, MI: WK Kellogg Foundation.

Landis, J., \& Koch, G. G. (1977). The Measurement of Observer Agreement for Categorical Data. Biometrics, 33, 159-174. https://www.jstor.org/stable/2529310 https://doi.org/10.2307/2529310

Laschinger, H. (2012). Conditions for Work Effectiveness Questionnaire I and II: User Manual.

Lennie, J., Tacchi, J., Koirala, B., Wilmore, M., \& Skuse, A. (2011). Equal Access Participatory Monitoring and Evaluation Toolkit: Helping Communication for Development Organizations to Demonstrate Impact, Listen and Learn, and Improve Their Practices. http://www.seachangecop.org/sites/default/files/documents/2011\%2002\%20EA\%20\%2 0Equal\%20Access\%20Participatory\%20Monitoring\%20and\%20Evaluation\%20Toolkit. pdf 
Maidin, N. F. (2012). Amalan organisasi pembelajaran di sekolah cemerlang: Satu kajian kes. Doctoral Dissertation, Selangor: Universiti Kebangsaan Malaysia. (In Malay)

Mainguet, C., \& Baye, A. (2006). Defining a Framework of Indicators to Measure the Social Outcomes of Learning. In R. Desjardins, \& T. Schullar (eds.), Measuring the Effects of Education on Health and Civic Engagement, Proceedings of the Copenhagen Symposium. Pairs: CERI, OECD.

Mansor, A. N., Maniam, P. P., Hunt, M. C., \& Nor, M. Y. M. (2016). Benefits and Disadvantages of Streaming Practices to Accommodate Students by Ability. Creative Education, 7, 2547-2558. https://doi.org/10.4236/ce.2016.717241

Ministry of Education Malaysia (2017a). Malaysia's National Education Blueprint Annual Report 2016. Putrajaya: Ministry of Education Malaysia.

Ministry of Education Malaysia (2017b). District Transformation Programme Guidebook 3.0. Putrajaya: Bahagian Pengurusan Sekolah Harian.

Mohamed Yusoff, M. N., Azlin Norhaini, M., \& Ashairi, S. (2018). The Practice of School Based Management: Special Reference to Malaysian Clusters Schools and UK Autonomous Schools. Journal of Advanced Research in Dynamical and Control Systems, 10 , 1618-1626.

Organization for Economic Co-Operation and Development OECD (2015). Education at Glance 2015.

Pallant, J. (2005). SPSS Survival Manual Second-Edition: A Step by Step Guide to Data Analysis Using SPSS. Sydney: Allen \& Unwin.

Park, J. H. (2006). Measurement and Validation of Senge's Learning Organization Model in Korean Vocational High Schools. Doctoral Dissertation, Athens, GA: University of Georgia.

Phang, F. A., Abu, M. S., Ali, M. B., \& Salleh, S. (2014). Faktor penyumbang kepada kemerosotan penyertaan pelajar dalam aliran sains: Satu analisis sorotan tesis. Sains $\mathrm{Hu}$ manika, 2, 63-71. (In Malay)

Radzi, N. M., Ghani, M. F. A., Siraj, S., \& Afshari, M. (2018). Financial Decentralization in Malaysian Schools: Strategies for Effective Implementation. MOJES: Malaysian Online Journal of Educational Sciences, 1, 20-32.

Rani, N. A., Sulaiman, W. I. W., \& Mahbob, M. H. (2018). Pengaruh budaya organisasi terhadap latihan dan pembangunan dalam kalangan kakitangan kumpulan sokongan di UPM. e-Bangi Journal of Social Sciences and Humanities, 11, 142-173. (In Malay)

Said, R. R., Brahim, M., \& Md Sabil, A. (2016). Bimbingan dan Pementoran Berfokus oleh SISC+ BM: Impak terhadap Kualiti Pengajaran Guru Bahasa Melayu di Sekolah-sekolah Menengah Daerah Samarahan, Sarawak. Jurnal Pendidikan Malaysia, 41, 131-139. (In Malay)

Singh, S. S. B., Rathakrishnan, B., Talin, R., \& Dg. Norizah Ag. Kiflee. (2017). Pengintegrasuan sistem maklumat Geografi (GIS) dalam pengajaran dan pembelajaran Goegrafi: kajian kes di sekolah bestari luar bandar di Sabah. Journal of Social Sciences and Humanities, 14, 1-14. (In Malay)

Thuss, M., Babenko-Mould, Y., Andrusyszyn, M.-A., \& Laschinger, H. K. S. (2016). Nursing Clinical Instructor Experiences of Empowerment in Rwanda: Applying Kanter's and Spreitzer's Theories. International Journal of Nursing Education Scholarship, 13, 117-125. https://doi.org/10.1515/ijnes-2014-0073

van Veelen, R., Sleegers, P. J. C., \& Endedijk, M. D. (2017). Professional Learning among School Leaders in Secondary Education: The Impact of Personal and Work Context Factors. Educational Administration Quarterly, 53, 365-408.

https://doi.org/10.1177/0013161X16689126 